\title{
Floristic characteristics of alien invasive seed plant species in China
}

\author{
CONGYAN WANG ${ }^{1}$, JUN LIU $^{1}$, HONGGUANG XIAO ${ }^{1}$, JIAWEI ZHOU $^{1}$ and DAOLIN DU ${ }^{1,2}$ \\ ${ }^{1}$ Institute of Environment and Ecology, Academy of Environmental Health and Ecological Security \& School \\ of the Environment and Safety Engineering, Jiangsu University, 212013 Zhenjiang, P.R. China \\ ${ }^{2}$ Key Laboratory of Modern Agricultural Equipment and Technology, Ministry of Education \\ and Jiangsu Province, Jiangsu University, 212013 Zhenjiang, P.R. China
}

Manuscript received on September 15, 2015; accepted for publication on December 17, 2015

\begin{abstract}
This study aims to determine the floristic characteristics of alien invasive seed plant species (AISPS) in China. There are a total of five hundred and thirteen AISPS, belonging to seventy families and two hundred and eighty-three genera. Seventy families were classified into nine areal types at the family level, and "Cosmopolitan" and "Pantropic" are the two main types. Two hundred and eighty-three genera were classified into twelve areal types at the genus level, and "Pantropic", "Trop. Asia \& Amer. disjuncted", and "Cosmopolitan" are the three main types. These results reveal a certain degree of diversity among AISPS in China. The floristic characteristics at the family level exhibit strong pantropic characteristics. Two possible reasons for this are as follows. Firstly, southeastern China is heavily invaded by alien invasive plant species and this region has a mild climate. Secondly, southeastern China is more disturbed by human activities than other regions in China. The floristic characteristics at the genus level display strong pantropic but with abundant temperate characteristics. This may be due to that China across five climatic zones and the ecosystems in which the most alien invasive plant species occur have the same or similar climate with their natural habitat.
\end{abstract}

Key words: alien invasive plant species, floristic characteristics, China, Compositae.

\section{INTRODUCTION}

In recent decades, anthropogenic activities have triggered unprecedented environmental changes on a global scale, such as biological invasion and these invaders can obviously alter the structure and/or functions of the ecosystems in which they occur (Loydi et al. 2015, Piper et al. 2015, Wang et al. 2016a). As the world's third largest country, China covers five climatic zones: cold-temperate, temperate, warm-temperate, subtropical, and

Correspondence to: Congyan Wang

E-mail: liuyuexue623@163.com tropical in which diverse ecosystems can receive a variety of alien invasive plant species from different biogeographic regions (Xie et al. 2001, Wu et al. 2006, Weber et al. 2008, Li et al. 2009). A wide range of habitats and environmental conditions enable China especially vulnerable to the successful establishment of the alien invasive floras originating from different regions because the potential alien invasive plant species from most areas of the world can find their suitable habitat somewhere in China ultimately (Xie et al. 2001, Weber et al. 2008, Yan et al. 2014). Meanwhile, China's rapid economic development in the $20^{\text {th }}$ 
century, including explosive growth in trade and transportation systems, is increasing the pathways for the introduction and spread of alien invasive plant species among regions within China and the introduction of new alien invasive species to China from other countries (Xie et al. 2001). Since many alien invasive plant species have long lag times from initial establishment until the appearance of a fullblown invasion, the full effects of the invaders arriving in China may not be felt until well into the $21^{\text {st }}$ century (Xie et al. 2001). There are five hundred and fifteen alien invasive plant species from seventy-two families and two hundred and eighty-five genera reported from China in 2014 (Yan et al. 2014). Flora is defined as the sum of all plant taxonomic units in one region within a certain period (Wang 1992). Understanding the floral characteristics of plants in one region is necessary to elucidate the plants' natural environment and the main characteristics of plant resources (Liu et al. 2011, Wang et al. 2016b). Additionally, the floristic analysis of alien invasive plant species is very important for their control and management (Wu et al. 2008). To date, some studies have investigated the floristic characteristics of alien plant species in China, such as Shandong Province, eastern China (Wu et al. 2008) and Henan Province, central China (Dong and Ye 2007).

This study aims to gain insights into the floristic characteristics of alien invasive seed plant species (AISPS) in China via literature review. We hypothesize that the floristic characteristics of AISPS in China display strong transitional characteristics from pantropic to temperate due to that China covers five climatic zones: cold-temperate, temperate, warm-temperate, subtropical, and tropical. In addition, ecosystems in which the most alien invasive plant species occur have the same or similar climate with their natural habitat. The results of this study can provide a platform to better underlying the profile of floristic characteristics of AISPS in China. Findings also lay an important theoretical foundation and practical significance for effective invasion prevention and control.

\section{MATERIALS AND METHODS}

The resources of AISPS in China were according to Yan et al. (2014). List of AISPS in China was illustrated in Table SI (supplementary material). The areal types of AISPS in China at the family level were determined according to the standard floristic classification of world families of seed plants reported by $\mathrm{Wu}$ et al. (2003) and Wu (2003). The areal types of AISPS in China at the genus level were determined according to the standard of floristic classification on Chinese genera of seed plants reported by Wu (1991, 1993).

The floristic characteristics of AISPS in China were characterized by using the R/T value. The $\mathrm{R} / \mathrm{T}$ value of the areal types of AISPS in China was computed using the ratio of the tropic components (2-7) to the temperate components (8-14) according to the methods used by Tian et al. (2013) and Zhu et al. (2015). In general, a high $\mathrm{R} / \mathrm{T}$ value indicates high tropical characteristics and a low $\mathrm{R} / \mathrm{T}$ value indicates high temperate characteristics.

Species differentiation $(S D)$ of AISPS in China was determined by using the following equation (Zhang 2007) to characterize the degree of floristic differentiation for AISPS in China:

$$
S D=N_{g} / N_{f}+N_{s} / N_{g}
$$

where $N_{f}, N_{g}$, and $N_{s}$ are the sums of the numbers of families, genera, and species of all AISPS in China, respectively. In particular, a high $S D$ value indicates greater differentiation and a low $S D$ value indicates less differentiation.

\section{RESULTS AND DISCUSSION}

PLANT COMPOSITION AND AREAL TYPES AT THE FAMILY LEVEL

Seventy families of AISPS exist in China (Table SI). The following families of AISPS in China are 
arranged in descending order based on the number of members: Compositae (fifty-four genera and ninetytwo species); Leguminosae (thirty-two genera and seventy-one species); Gramineae (thirty-one genera and fifty-nine species); Solanaceae (seven genera and twenty-four species); Amaranthaceae (four genera and twenty-two species); Euphorbiaceae (six genera and twenty-one species); Cruciferae (eleven genera and fifteen species); Onagraceae (five genera and fifteen species); Convolvulaceae (four genera and fifteen species); Chenopodiaceae and Lamiaceae (five genera and ten species); Scrophulariaceae (five genera and nine species); Caryophyllaceae (eight genera and eight species); Malvaceae (seven genera and eight species); Umbelliferae and Acanthaceae (five genera and six species); Rubiaceae and Verbenaceae (four genera and six species); Cactaceae and Amaryllidaceae (three genera and five species); Myrtaceae (two genera and five species); Passifloraceae (one genus and five species); Nyctaginaceae and Boraginaceae (three genera and four species); Portulacaceae, Ranunculaceae, and Crassulaceae (two genera and four species); Oxalidaceae (one genus and four species); Polygonaceae, Lythraceae, Bignoniaceae, and Commelinaceae (three genera and three species); Basellaceae and Campanulaceae (two genera and three species); Plantaginaceae and Cyperaceae (one genus and three species) (Table SI). Furthermore, two AISPS of each of the following families exist in China: Urticaceae, Phytolaccaceae, Piperaceae, Papaveraceae, Balsaminaceae, Liliaceae, Iridaceae, and Araceae (Table SI). Only one AISPS of each of the following families exist in China: Casuarinaceae, Moraceae, Aizoaceae, Nymphaeaceae, Capparidaceae, Resedaceae, Geraniaceae, Anacardiaceae, Aceraceae, Vitaceae, Tiliaceae, Sterculiaceae, Begoniaceae, Cucurbitaceae, Sonneratiaceae, Melastomataceae, Haloragaceae, Apocynaceae, Asclepiadaceae, Martyniaceae, Orobanchaceae, Butomaceae, Hydrocharitaceae, Pontederiaceae,
Lemnaceae, and Marantaceae (Table SI). Thus, thirty-six families comprising three or more AISPS (51.43\%), eight families including only two AISPS (11.43\%), and twenty-six families comprising only one AISPS (37.14\%) are found in China. The aforementioned findings indicate that AISPS in China show a certain degree of diversity at the family level. This may be due to the blind introduction (includes unintentional and intentional activities) of foreign species in China in recent decades (Xie et al. 2001). This phenomenon may also be a contributing factor to the long lag times from initial establishment until the appearance of a fullblown invasion (Xie et al. 2001).

According to the standard floristic classification of world families of seed plants proposed by $\mathrm{Wu}$ et al. (2003) and Wu (2003), seventy families of AISPS in China may be classified into nine areal types at the family level (Table I). In particular, "Cosmopolitan" comprises twenty-nine families (41.43\%), "Pantropic" comprises twentytwo families (31.43\%), "N. Temp. \& S. Temp. disjuncted" comprises three families (4.29\%), and "Trop. Asia, Africa \& C. to S. Amer. disjuncted" comprises two families (2.86\%) (Table I). The three areal types, namely, "Pantropic especially S. Hemisphere", "Trop. Asia \& Amer. disjuncted", and "N. Temp.," involve four families, accounting for $5.71 \%$ of the observed plants (Table I). The two areal types, namely, "Old World Tropics" and "Trop. Asia \& Trop. Oceania", include only one family, accounting for $1.43 \%$ of the found species (Table I). Thus, a large proportion of AISPS in China may be classified under pantropic components. The $\mathrm{R} / \mathrm{T}$ value of the areal types of AISPS in China at the family level is about 4.86 which is obviously greater than 1 (Table II). Thus, the floristic characteristics of AISPS in China at the family level exhibit strong pantropic characteristics. This observation is inconsistent with the hypothesis. This might indicate that southeastern China is heavily infested with alien invasive plant species, 
presumably because this part of the country has a mild climate (mainly subtropical and tropical) and is more disturbed by human activities than other regions in China (Wu et al. 2006, Li et al. 2009, Feng et al. 2010). Thus, the AISPS in China contains abundant pantropic elements at the family level.

PLANT COMPOSITION AND AREAL TYPES AT THE GENUS LEVEL

Two hundred and eighty-three genera of AISPS exist in China (Table SI). Euphorbia and
Amaranthus comprise the largest number of AISPS (fifteen and fourteen species, respectively) in China at the genus level with a total of $10.25 \%$ (Table SI). Forty-four genera comprising three or more AISPS (15.55\%) (Table SI). Fifty-one depauperate genera including two species (18.02\%) and one hundred and eighty-eight monotypic genera comprising one species $(66.43 \%)$ are also observed (Table SI). Thus, a number of genera of AISPS exist in China, but these genera are dominated by depauperate or monotypic types.

TABLE I

The areal types of AISPS in China.

\begin{tabular}{|c|c|c|c|c|c|}
\hline $\begin{array}{c}\text { The areal } \\
\text { types }\end{array}$ & Name of the areal types & $\begin{array}{l}\text { No. of } \\
\text { family }\end{array}$ & $\begin{array}{c}\text { The percentage } \\
\text { of family }\end{array}$ & $\begin{array}{l}\text { No. of } \\
\text { Genera }\end{array}$ & $\begin{array}{c}\text { The percentage } \\
\text { of genera }\end{array}$ \\
\hline 1 & Cosmopolitan & 29 & $41.43 \%$ & 34 & $12.01 \%$ \\
\hline 2 & Pantropic & 22 & $31.43 \%$ & 70 & $24.74 \%$ \\
\hline $2-1$ & $\begin{array}{l}\text { Trop. Asia, Australasia (to N. Zeal.) \& C. to S. Amer. (or } \\
\text { Mexico) disjuncted }\end{array}$ & & & 2 & $0.71 \%$ \\
\hline $2-2$ & Trop. Asia, Africa \& C. to S. Amer. disjuncted & 2 & $2.86 \%$ & 12 & $4.24 \%$ \\
\hline $2 \mathrm{~S}$ & Pantropic especially S. Hemisphere & 4 & $5.71 \%$ & & \\
\hline 3 & Trop. Asia \& Amer. disjuncted & 4 & $5.71 \%$ & 64 & $22.61 \%$ \\
\hline 4 & Old World Tropics & 1 & $1.43 \%$ & 8 & $2.83 \%$ \\
\hline 5 & Trop. Asia \& Trop. Oceania & 1 & $1.43 \%$ & 2 & $0.71 \%$ \\
\hline 6 & Trop. Asia \& Trop. Africa & & & 7 & $2.47 \%$ \\
\hline 7 & Trop. Asia (Indo-Malesia) & & & 2 & $0.71 \%$ \\
\hline 8 & N. Temp. & 4 & $5.71 \%$ & 21 & $7.42 \%$ \\
\hline $8-3$ & Arctic to Altai \& N. Amer. disjuncted & & & 1 & $0.35 \%$ \\
\hline $8-4$ & N. Temp. \& S. Temp. disjuncted & 3 & $4.29 \%$ & 11 & $3.89 \%$ \\
\hline 9 & E. Asia \& N. Amer. disjuncted & & & 12 & $4.24 \%$ \\
\hline $9-1$ & E. Asia \& Mexico disjuncted & & & 2 & $0.71 \%$ \\
\hline 10 & Old World Temp. & & & 14 & $4.95 \%$ \\
\hline $10-1$ & Mediterranea. W. Asia (or C. Asia) \& E. Asia disjuncted & & & 2 & $0.71 \%$ \\
\hline $10-2$ & Mediterranea \& Himalaya disjuncted & & & 2 & $0.71 \%$ \\
\hline $10-3$ & $\begin{array}{c}\text { Eurasia \& S. Africa (Sometimes also Australasia) } \\
\text { disjuncted }\end{array}$ & & & 4 & $1.41 \%$ \\
\hline 12 & Medit., W. \& C. Asia & & & 12 & $4.24 \%$ \\
\hline 13 & C. Asia & & & 1 & $0.35 \%$ \\
\hline
\end{tabular}

TABLE II

The R/T value of the areal types of AISPS in China both at the family and genus levels.

\begin{tabular}{ccc}
\hline & Family & Genera \\
\hline No. of the tropic components (2-7) & 34 & 167 \\
No. of the temperate components (8-14) & 7 & 82 \\
R/T value & 4.86 & 2.04 \\
\hline
\end{tabular}


According to the standard floristic classification of Chinese genera of seed plants proposed by $\mathrm{Wu}$ (1991, 1993), two hundred and eighty-three genera of AISPS in China may be classified into twelve areal types at the genus level (Table I). In particular, "Pantropic" comprises seventy genera (24.74\%), "Trop. Asia \& Amer. disjuncted" involves sixtyfour genera (22.61\%), "Cosmopolitan" includes thirty-four genera (12.01\%), "N. Temp." comprises twenty-one genera (7.42\%), "Old World Temp." comprises fourteen genera (4.95\%), "N. Temp. \& S. Temp. disjuncted" includes eleven genera (3.89\%), "Old World Tropics" comprises eight genera (2.83\%), "Trop. Asia \& Trop. Africa" involves seven genera (2.47\%), "Eurasia \& S. Africa (Sometimes also Australasia) disjuncted" include four genera (1.41\%) (Table I). The three areal types, namely, “Trop. Asia, Africa \& C. to S. Amer. disjuncted", "E. Asia \& N. Amer. disjuncted", and "Medit., W. \& C. Asia" involves twelve genera (4.24\%) (Table I). The six areal types, namely, "Trop. Asia, Australasia (to N. Zeal.) \& C. to S. Amer. (or Mexico) disjuncted", "Trop. Asia \& Trop. Oceania", "Trop. Asia (Indo-Malesia)", "E. Asia \& Mexico disjuncted", "Mediterranea. W. Asia (or C. Asia) \& E. Asia disjuncted", and "Mediterranea \& Himalaya disjuncted", comprised two genera $(0.71 \%)$. The two areal types, namely "Arctic to Altai \& N. Amer. disjuncted" and "C. Asia”, consist of only one genus (0.35\%) (Table I). A large proportion of the plants exhibit temperate and pantropic distributions. The $\mathrm{R} / \mathrm{T}$ value of the areal types of AISPS in China at genus level is 2.04 (Table II). Thus, the floristic characteristics of AISPS in China at the genus level display strong pantropic but with abundant temperate characteristics. The result is consistent with the hypothesis. The result may be due to that China across five climatic zones, namely, cold-temperate, temperate, warm-temperate, subtropical, and tropical (Xie et al. 2001, Wu et al. 2006, Weber et al. 2008, Li et al. 2009). Additionally, ecosystems in which the most alien invasive plant species occur have the same or similar climate with their natural habitat. Thus, the floristic characteristics of AISPS in China exhibit strong transition characteristics from pantropic to temperate at the genus level.

Plant Composition AT THE SPECIES LEVEL

Five hundred and thirteen species of AISPS exist in China and belong to seventy families and two hundred and eighty-three genera (Table SI). The family with most AISPS (ninety-two species) was Compositae (17.93\%, Table SI). As one of the highest evolutionary status of plant groups, composite species successfully invade many environments because those species feature fecundity and high-efficiency multiple reproduction modes. This phenomenon may also be a contributing factor to the dormancy and the rapid spread of their seeds that can enable them to occupy a wide variety of environmental conditions (Fumanal et al. 2007, Yan et al. 2014). The value of species differentiation of AISPS in China was approximately 5.86. The high degree of floristic differentiation of AISPS in China may be attributed to the multivariate environments in which those invaders occur. This result may also be ascribed to that the alien invasive floras which exist in China via unintentional and intentional introduction originating from most areas of the world.

\section{ACKNOWLEDGMENTS}

This study was supported by National Natural Science Foundation of China (31300343, 31570414), Natural Science Foundation of Jiangsu Province, China (BK20130500), Universities Natural Science Research Project of Jiangsu Province, China (13KJB610002), Jiangsu Collaborative Innovation Center of Technology and Material of Water Treatment, Research Foundation for Advanced Talents, Jiangsu University (12JDG086). We are grateful to the anonymous 
reviewers for their insightful and constructive comments that improved this manuscript greatly.

\section{RESUMO}

Este estudo tem por objetivo determinar as características florísticas de espécies exóticas invasoras de plantas com sementes (EEIPS) na China. Há um total de quinhentas e treze EEIPS, pertencentes a duzentos e oitenta e três gêneros. Setenta famílias foram classificadas em nove tipos de distribuição ao nível de família. "Cosmopolita" e "Pantropical" são os tipos principais. Duzentos e oitenta e três gêneros foram classificados em doze tipos de distribuição ao nível de gênero. "Pantropical", "Asia Trop. \& Amer. disjuntas" e "Cosmopolita" são os três tipos principais. Estes resultados revelam certo grau de diversidade entre EEIPS na China. As características florísticas ao nível de família exibem fortes características pantropicais. Duas possíveis razões para isso são as seguintes. Primeiramente, o sudeste da China é fortemente invadido por espécies alienígenas invasivas e esta região possui clima ameno. Em segundo lugar, o sudeste da China é mais perturbado por atividades humanas do que outras regiões da China. As características florísticas ao nível de gênero mostram forte distribuição pantrópica, mas com abundantes características temperadas. Isto pode ocorrer porque a China cruza cinco zonas climáticas e os ecossistemas nos quais a maioria das espécies invasoras ocorre tem o mesmo clima de seu habitat natural ou similar.

Palavras-chave: espécies vegetais exóticas invasoras, características florísticas, China, Compositae.

\section{REFERENCES}

DONG DP AND YE YZ. 2007. Studies on Flora Alien Invasive Plants and Disastrous Mechanisms in Henan. Henan Sci 25: 765-769.

FENG JM, DONG XD AND XU CD. 2010. Spatial patterns of species diversity of alien invasive plants in China and their relationship with native plants. J Southwest Univ (Nat Sci Edit) 32: 50-57.

Fumanal B, Chauvel B, SABAtier A AND BRETAGNOLLE F. 2007. Variability and cryptic heteromorphism of Ambrosia artemisiifolia seeds: what consequences for its invasion in France? Ann Bot 100: 305-313.

LI BO ET AL. 2009. Spartina alterniflora invasions in the Yangtze River estuary, China: An overview of current status and ecosystem effects. Ecol Eng 35: 511-520.
LIU BG, KONG GJ, WANG CY, HU Y AND ZHenG XJ. 2011. Floristic study of wild evergreen broad-leaved woody plants in Henan. J Henan Agr Univ 2: 226-230.

LOYdi A, DONATH TW, ECKSTEIN RL AND OTTE A. 2015. Non-native species litter reduces germination and growth of resident forbs and grasses: allelopathic, osmotic or mechanical effects? Biol Invasions 17: 581-595.

PIPER CL, Siciliano SD, Winsley T AND LAMB EG. 2015. Smooth brome invasion increases rare soil bacterial species prevalence, bacterial species richness and evenness. J Ecol 103: 386-396.

TIAN HZ, DONG QY AND LI HQ. 2013. Comparison of Orchidaceae flora in 38 regions of China. Acta Bot BorealOccident Sin 33: 808-823.

WANG HS. 1992. Floristics. Beijing: Science Press, p. 1.

WANG CY, LIU J AND XIAO HG. 2016b. Floristic characteristics of woody plants in Mount Jiao. J West China For Sci 45: 30-37.

WANG CY, XIAO HG, ZHAO LL, LIU J, WANG L, ZHANG F, SHI YC AND DU DL. 2016a. The allelopathic effects of invasive plant Solidago canadensis on seed germination and growth of Lactuca sativa enhanced by different types of acid deposition. Ecotoxicology 25: 555-562.

WEBER E, SUN SG AND LI B. 2008. Invasive alien plants in China: diversity and ecological insights. Biol Invasions 10: 1411-1429.

WU T, LI J, DAI J AND WANG R. 2008. Floristic analysis and distribution pattern of alien plants in Shandong Province, eastern China. Front For China 3: 219-225.

WU XW, LUO J, CHEN JK AND LI B. 2006. Spatial patterns of invasive alien plants in China and its relationship with environmental and anthropological factors. J Plant Ecol 30: $576-584$.

Wu ZY, ZHOU ZK, LI DZ, PENG H AND SUN H. 2003. The areal-types of the world families of seed plants. Acta Bot Yunnanica 3: 245-257.

WU ZY. 1991. The areal-types of Chinese genera of seed plants. Acta Bot Yunnanica Z: 1-139.

WU ZY. 1993. The revision of "The areal-types of Chinese genera of seed plants". Acta Bot Yunnanica Z: 141-178.

WU ZY. 2003. The revision of "The areal-types of the world families of seed plants". Acta Bot Yunnanica 5: 535-538.

XIE Y, Li ZY, GREGG WP AND DiAnMo L. 2001. Invasive species in China-an overview. Biodivers Conserv 10: 1317-1341.

YAN XL, LIU QR, SHOU HY, ZENG XF, ZHANG Y, CHEN L, LIU Y, MA HY, QI SY AND MA JS. 2014. The categorization and analysis on the geographic distribution patterns of Chinese alien invasive plants. Biodivers Sci 22: 667-676.

ZHANG GF. 2007. Plant diversity of Anhui Banqiao natural protection area. Nanjing: Nanjing Normal University Press, p. 7. 
ZHU H, KU WP, Rong JT AND XIANG JE. 2015. Species diversity and floristic characteristics of vascular plants in Nanji Island, Zhejiang Provience. Plant Diversity Resour 37: 713-720.

\section{SUPPLEMENTARY MATERIAL}

TABLE SI - Check list of AISPS in China (according to Yan et al. 2014). 